症例

直腸粘膜脱を契機に発見された高齢者鎖肛（直腸䐋前庭㾞）の 1 例

国立長野病院外科

$\begin{array}{lllll}\text { 石曾根 } & \text { 聡 千須和 寿 } \text { 直 清 水 文 彰 } \\ \text { 土屋 拓 } & \text { 司 岡 本 講 } \text { 平 }\end{array}$

症例は84歳，女性。幼少時，母親から肛門の位置異常を指摘されたことがあったが本 人の自覚はなかった． 1 年前より膣から粘膜の脱出を自覚，徐々に増大を認めたため当 院受診した，会陰部には本来あるべき位置に肍門は認めず，軽度の陥凹を認めるのみで あった。指診にて臸後壁に直腸が開口しているのが確認され，直腸粘膜がポリープ状に 胵内に脱出していた，MRIでは直腸が胵後壁に開口しているのが確認され直腸堙前庭瘦 と診断した。脱出した直腸粘膜切除のみ行った。病理組織検查では mild atypia を示す tubular adenoma と診断された。

鎖肛は一般的に新生時期に外科的治療を要するが例外的に成人に達する場合もある。 本症例は84年間自覚症状なく，直腸粘膜の脱出を契機に鎖肛（直腸腔前庭瘦）の診断に 至った極めて稀な例である．成人に達した直腸肛門奇形では，日常生活に差し障る症状 がない場合，外科的処置が不必要な場合もあると考えられた。

索引用語：鎖肛, 直腸堙前庭瘦, 成人

\section{緒 言}

先天性直腸肛門奇形（鎖肛）は一般に新生時期に発 見され，外科的治療が必要とされる疾患である。著者 らは84年間自覚症状なく経過し，瘦孔部より直腸粘膜 が脱出したことにより初めて発見され診断に至った， 高齢者先天性直腸肛門奇形の 1 例を経験したので報告 する。

\section{症 例}

症例：84歳，女性.

主訴：膣より粘膜の脱出, 分泌液の增加.

既往歴: 姡娠 3 回, 出産 3 回.

現病歴：幼少時，母親から肛門の位置異常を指摘さ れたことがあったが本人の自覚はなかった，便秘およ び便失禁などの排便障害や排尿障害も認めなかった。 1997年初旬より, 䐋口より粘膜がポリープ状に脱出し ているのに気が付いた，徐々に增大し，分泌液も認め るようになったため1998年 9 月, 当院受診した。

初診時現症：身長 $139 \mathrm{~cm}$, 体重 $41 \mathrm{~kg}$. 頸部, 胸部に

2005 年 4 月14日受付 2005 年 6 月20日採用

〈所属施設住所〉

テ386-8610 上田市緑が丘 1-27-21
変形なく, 腹部は平坦, 軟. 四肢に変形, 奇形なども なし.

局所所見：会陰部には本来あるべき位置に肛門は認 めず, 軽度の陌凹を認めるのみであった，指診にて胵 後壁に直腸が開口しているのが確認され，開口部より $5 \times 4 \mathrm{~cm}$ 大の直腸粘膜がポリープ状に脱出してい た. 外尿道口は通常の位置に認められた（図 1 ).

血液検査所見：血液生化学検査所見では異常所見は 認められなかった。

MRI 所見：矢状断にて臸後壁に直腸が開ロしてい るのが確認された（図2）.

治療経過：現在まで排便機能に不自由なく生活をし てきており，直腸堙瘦に対しては根治治療の必要性は ないと考えられた。しかし，脱出している直腸粘膜が 徐々に增大し，分泌液が多く苦慮していることょり， 治療は脱出している直腸粘膜切除を施行した.

手術所見：全身麻酔下にて脱出した直腸粘膜切除術 を施行した（図 3 ).

病理組織所見：mild atypiaを示す tubular adenoma と診断された（図 4).

術後経過：経過は良好で第12病日退院となった，以 降術前の症状は消失し現在に至る。 


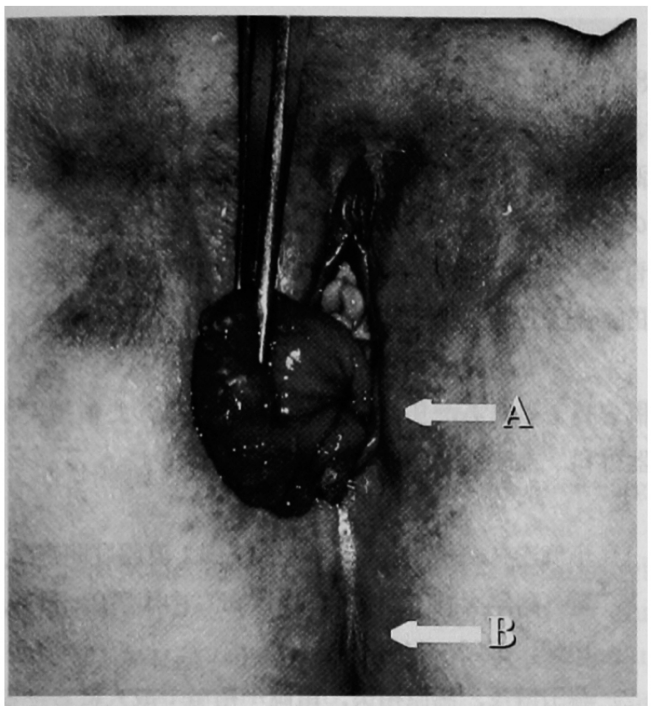

図 1 術前局所所見 (A：瘦孔開口部, B：肛門窝)

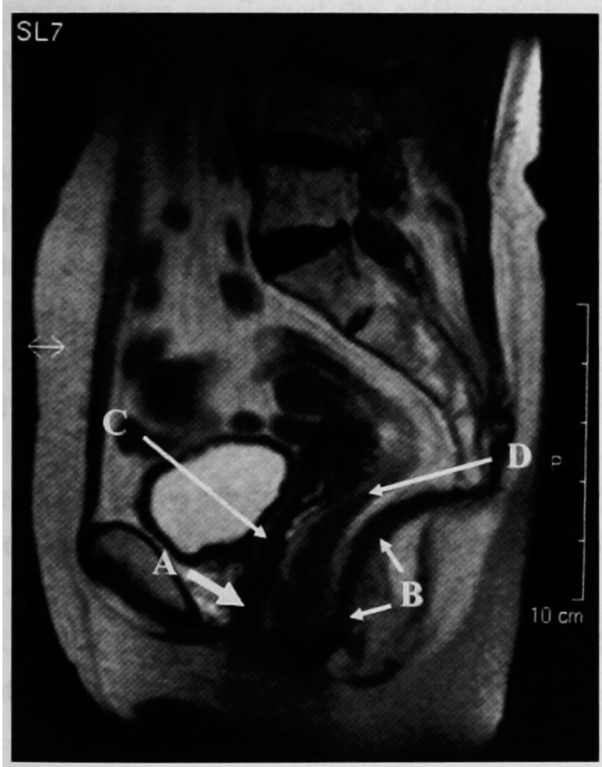

図 2 MRI 所見 (T2 強調像)：矢状断にて䐋後 壁に直腸が開ロしているのが確認された（A： 嗐孔開口部, $\mathrm{B}$ : 肛門挙筋, $\mathrm{C}$ : 䐋内腔, $\mathrm{D}$ : 直腸内腔).

考察

先天性直腸肛門奇形（鎖肛）は直腸および肛門の発 生異常によるもので, 会陰部いわゆる肛門窝に正常肛 門の開口を有しない奇形である. 発生頻度は5,000出生 に 1 例の割合で認められ，男女別比率は $1 \sim 1.5: 1^{1)}$ とされ新生児外科疾患のなかでも最も頻度の高いもの

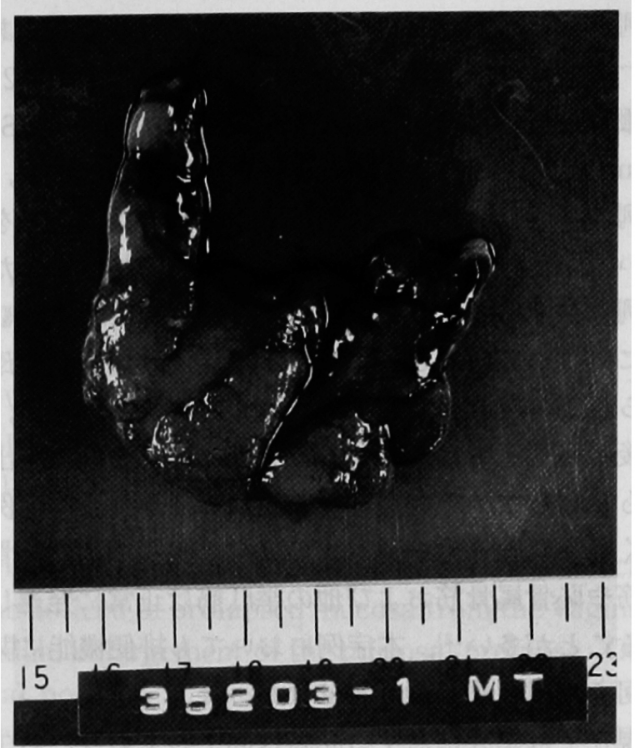

図 3 手術所見：切除した直腸粘膜.

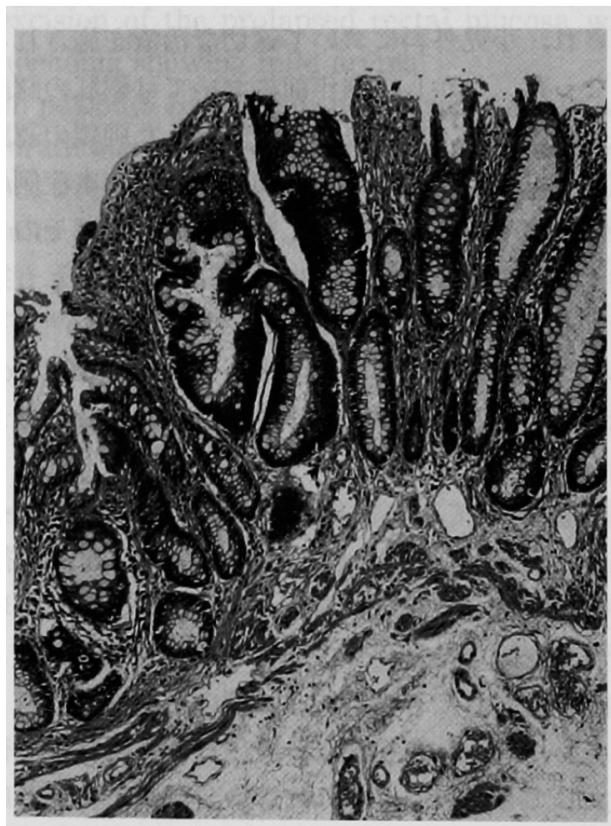

図 4 病理組織所見：mild atypia を示す tubu-

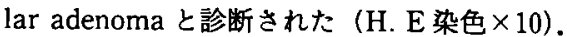

の一つであるが，通常は小児期に外科的処置がなされ ている.しかしごく稀に成人期まで放置されている例， もしくは本症例のごとく成人期に偶然に発見された例 も報告がある，われわれが検索しえた範囲では，本邦 において，成人での直腸肛門奇形の報告例は藤田らの 
2 例をはじめとする数例が報告されているのみであっ

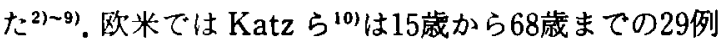
の報告をはじめ, Keighley"11の報告がある。また, Simmang ら ${ }^{12)}$ は43歳の女性の症例を報告しているが，本 症例のように84歳という高齢者で報告は他に例をみ ない. 藤吉ら 肛例は女性に多く, しかも大半が治療前にはすでに異 常に気付いているとしている. 本症例は幼少期に母親 から肛門の位置異常を指摘されたことはあったが，そ の後の自覚症状は全くなく, 3 回にわたる好娠, 出産 にも関わらず84年間自覚なく生活してきた．本症例の 如く恥骨直晹係締を通過する低位の鎖肛では, 恥骨直 腸筋や恥骨尾骨筋㧍よび他の举肛筋は正常に発達して いることが多い(13). 本症例においても排便機能に関し て何ら支障を感じることはなかった。

現在では鎖肛に対する認識は向上して掞り，新生時 期や乳児期に肛門の形態異常, 開口異常, 排便異常な どで産科医，小児科医を受診することにより，適切に 診断され，小児外科において適切な治療を施されるよ うになった。しかし，84年前においては鎖肛の認識も さほど高くなく，また，それを発見した両親の認識も 現在ほどは高くはなかったであろう．特に本症例の様 な排便障害や機能異常を伴わない鎖肛例ではそのまま 見過ごされたり気付かれずに経過していることも実際 には少なくはないのではないかと推測される4．しか し、小児外科の発展に伴い今後このような carry over 症例に遭遇することはますます少なくなることは予想 される。

治療に関して，本来新生児期であれば Posterior Sagittal Ano-Rectoplastyに倣った会陰式造肛術な どが行われるところであるが, 本症例においては現在 まで何も支障なく生活してきており，また，84歳とい う年齢を考慮しても根治的な治療の必要性はないと考 えられた.しかし, 瘦孔部より脱出した直腸粘膜が徐々 に増大してきており，それに伴い分泌物が多く苦慮し ていることを考虑し脱出した直腸壁のみ切除を行っ た。切除した直腸粘膜は mild atypia を示す tubular adenoma と診断された. 鎖肛とその瘦孔部にできた腺 腫とは因果関係があるか否かは不明である。脉吉ら は高位鎖肛の直腸総排泄腔部に癌が発生した例を報告 しており, 癌発生上の点に扔いては尿の関与も示唆し ている.本症例において尿の関与は明らかでない.むし 万長年における機械的刺激が，直腸粘膜の変化に何ら かの影響を及ほしてきたのではないかと推測される。

\section{結 語}

84年間何の自覚症状もなく経過し，直腸臸前庭瘦孔 部より直腸粘膜が脱出したことにより初めて発見され た高齢者先天性直腸肛門奇形の 1 例を経験したので若 干の文献的報告を加え報告した，成人に達した直腸肛 門奇形では，日常生活に差し障る症状がない場合，外 科的処置が不必要な場合もあると考えられた。

\section{謝 辞}

稿を終えるにあたりここ指導いただきました信州大学消 化器外科，丸田福門先生に深謝申し上げます。

\section{文献}

1）小柳泰久，里村紀作，木村幸三郎：直腸肛門奇形. 新外科学大系, 小児外科 $\mathrm{IV}, 30 \mathrm{D}$, 中山書店, 東京, 1990, p109-140

2）藤田博茂，㟫原裕夫，重岡一裕他：成人における 先天性直腸肛門奇形（銷肛）の 2 例. 四国医誌 $38: 70-73,1982$

3）平野敬八郎，㿝谷寿彦，鉿木義雄他：鎖肛抢よび いわゆる異所性肛門を中心として．日本大腸肛門 病会誌 $26: 185-186,1973$

4）平野敬八郎，渡辺 聖，中村博志他：小児外科の キャリーオーバー診療 成人にみられた直腸肛門 奇形 25歳男子高位銷肛（直腸尿道瘦）の1治験 例。 小児外科 $29: 661-668 ， 1997$

5）藤吉 学, 白水和雄，佐々木孝之他：成人鎖肛の 総排泄腔部に発生した腺癌の 1 例。日消外会誌 $20: 2685-2688,1987$

6) 内藤真一, 岩淵 真, 大沢義弘他：画像と手術時 の診断で discrepancy を示した成人鎖肛の 1 例. 臨外 47：405-407, 1992

7）黑崎伸子, 酒井 敦, 下山孝俊他：15歳以上にみ られた小児外科疾患一腸回転異常症, Hirschsprung 病，低位銷肛. 日臨外医会詓 51 (增刊号)： 103, 1990

8）家近誠治，谷川龍彦，緒方二郎他：鎖肛を伴った 陰茎前位陰叟の 1 例。日泌会誌 $79: 1602,1988$

9）横田勝正, 大川真澄, 津田英彦他：33葴まで高位 肛門狭窝のあった 1 症例。日消病会誌 $71: 185$, 1974

10) Katz LD, Zinkin LD, Stonesifer GL, et al : Imperforate anus and ectopic orfices in adult patient. Dis Colon Rectum 21 : 633-635, 1978

11) Keighley $M R: R e$-routing procedures for ectopic anus in the adult. Br J Surg $73: 974-$ 
977,1986

12) Simmang CL, Paquette E, Tapper D, et al: Posterior sagittal anorectoplasty:primary repair of a rectovaginal fistula in an adult : report of a case. Dis Colon Rectum $40: 1119-$ 1123,1997

13）角田昭夫：鎖肛の手術と肛門機能.外科 $38: 238$ $-247,1976$

\title{
A CASE OF IMPERFORATE ANUS (RECTOVESTIBULAR FISTULA) IN AN AGED PATIENT PRESENTED WITH MUCOSAL PROLAPSE
}

\author{
Satoshi ISHIZONE, Hisanao CHISUWA, Fumiaki SHIMIZU, \\ Takuji TSUCHIYA and Kohei OKAMOTO \\ Department of Surgery, National Nagano Hospital
}

The patient was an 84-year-old woman who had been unconscious of dislocation of the anus which had been pointed out by her mother from her childhood. She noticed of prolapsed mucosa from the vagina one year ago and was seen at the hospital because of a gradual enlargement of the mucosal prolapse. On physical examination no anus was identified at its natural position in the perineum and only a slight concavity was seen. A digital examination confirmed that the rectum opened at the posterior wall of the vagina, through which rectal mucosa prolapsed into the vagina in a shape of a polyp. Magnetic resonance imaging scans confirmed the orifice of the rectum opened on the vaginal posterior wall. Accordingly rectovestibular fistula was diagnosed. At surgery only excision of the prolapsed rectal mucosa was performed. The histopathological diagnosis was tubular adenoma showing mild atypia.

Imperforate anus generally requires surgical therapy in newborn babies, but it is rarely held intact until adulthood. This is an extremely rare case of imperforate anus (rectovestibular fistula) presented with mucosal prolapse after an 84 -year asymptomatic period. In the case of anorectal anomaly held until the patient's adulthood, surgical therapy might be sometimes unnecessary if he or she does not have symptoms which disturb his or her daily activities. 